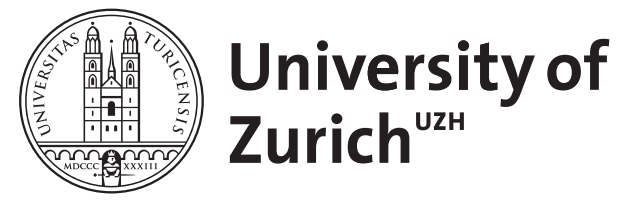

Zurich Open Repository and Archive

University of Zurich

University Library

Strickhofstrasse 39

CH-8057 Zurich

www.zora.uzh.ch

Year: 2010

Reforming European financial supervision and the role of EU institutions

Alexander, Kern

Posted at the Zurich Open Repository and Archive, University of Zurich

ZORA URL: https://doi.org/10.5167/uzh-47009

Journal Article

Originally published at:

Alexander, Kern (2010). Reforming European financial supervision and the role of EU institutions. Amicus Curiae, 82:2-11. 


\title{
Reforming European \\ financial supervision and the role of EU institutions
}

\author{
by Kern Alexander
}

\section{INTRODUCTION}

The growing integration of European financial markets and the financial crisis of 2007-09 have raised important questions concerning the institutional design of European financial supervision. Over 50 large financial institutions have significant cross-border operations in EU states, while wholesale capital markets are increasingly inter-connected across EU states through electronic exchanges and other complex trading systems. Over the last 10 years, EU financial legislation has grown dramatically in its scope of coverage and application to many areas of market practice. The implementation and enforcement of this legislation has been left ultimately to the discretion and authority of Member State supervisors based on the principle of home country control and mutual recognition. Although this legal and supervisory framework facilitated cross-border trade and investment across EU states, the adoption of the euro and the institutional consolidation of the Lamfalussy process have led to calls for further consolidation of supervisory practices at the EU level. Moreover, the recent financial crisis has demonstrated the importance of having a robust macro-prudential supervisory framework and micro-prudential supervisory regime with the objective of controlling systemic risk.

The European Commission has proposed a significant institutional restructuring of EU financial supervision that involves the creation of a European Systemic Risk Board to monitor macro-prudential risks and three EU supervisory authorities to adopt a regulatory code and to oversee Member States' micro-prudential supervision. The Commission proposals, if approved by the EU Parliament, will lead to significant institutional consolidation at the EU level. This will bring important changes to the existing EU framework of financial supervision that is based on home country control and mutual recognition. It also has important implications for international supervisory and regulatory arrangements because the proposed EU financial supervisory authorities (ESAs) and ESRB are likely to play a significant role in setting the international regulatory agenda. The overarching philosophical rationale for designing the ESRB/ESA institutional structure is that systemic risk and financial instability create negative externalities in European financial markets and it is a necessary policy objective of the European Union institutions to control financial risks that can threaten the efficient operations of the internal market.

This article discusses generally how the growing integration of EU financial markets and the cross-border nature of systemic risk justify a more consolidated institutional model of EU financial supervision. In doing so, it will address some of the advantages and disadvantages of other models, including the proposal for a single EU supervisor. The nature of systemic risk in liberalised financial markets creates significant risks for supervisors and policymakers seeking to protect their economic and financial systems from the fallout of financial failure. This article suggests that the cross-border nature of European financial markets and consequently the cross-border risks posed by financial instability necessitate a re-examination of the institutional design of European financial supervision.

\section{EUROPEAN FINANCIAL INTEGRATION AND SYSTEMIC RISK}

The causes of the recent crisis have been attributed to macroeconomic factors, major weaknesses in corporate governance in financial institutions, and serious regulatory failings. The costs of the crisis for EU Member States have been enormous. In the UK, the cost of the crisis in terms of lost output and lower economic growth has been estimated at more than 19 per cent of UK GDP. It is evident that poorly regulated financial markets can lead to huge social costs for the broader economy and that these social costs in regional and globalised markets can be exported to other economies. Indeed, EU states are members of the European Union's internal market with free capital flows and fully liberalised trade in financial services which brings economic benefits but also social costs when markets fail for the economies of EU states. For example, the collapse of the Royal Bank of Scotland 
demonstrated how the risk-taking of a Member State bank can generate cross-border externalities to other EU countries and financial systems. It is essential therefore that Europe have a more comprehensive framework for regulating and controlling the social costs (otherwise known as "negative externalities") of financial risk-taking. These externalities can be transmitted more easily throughout EU financial markets because of the greater degree of financial integration in recent years due to financial liberalisation in the internal market.

A vast literature has emerged documenting the growing integration of European financial markets (Adam et al, 2002; Cabral et al, 2002; Barros et al, 2004; ECB 2008 \& 2009; Commission 2009). Following adoption of the euro, there has been significant convergence in interest rate differentials in the wholesale banking and inter-bank markets. Although retail financial markets remain mostly fragmented, the cost of capital for equity and debt issuance has experienced a significant degree of convergence across EU states, while the composition of asset classes in most regulated investment funds has become less home-biased towards the domestic market. However, since the global financial crisis began in 2007, the 27 EU states have had wider dispersions in their cost of capital - the European Commission, European Financial Integration Report 2009, Brussels December 11, 2009, Commission Staff Working Document, p 4. The report also notes that the dispersions in cost of capital between EU countries began to converge more in the last half of 2009, presumably in response to the stock market's recovery in the second quarter of 2009.

The evolution of EU markets to more integrated structures based on liberalisation of capital restrictions and trade in financial services has been facilitated by the growing importance of the euro as a reserve currency and advances in technology that enable market participants to operate more easily in a cross-border environment. The challenge arising from the increasing integration of European and global financial markets and the recurrence of financial crises, such as the crisis that began in 2007, is how to strike the right institutional balance between EU institutions and Member States in the regulation and supervision of financial markets. (see Edy Wymeersch (2009), "The Structure of Financial Supervision in Europe: About Single Financial Supervisors, Twin Peaks and Multiple Financial Supervisors," European Business Organization Law Review 8: 237-306 (stating that "regulation" refers essentially to rule-making, while "supervision" involves applying the rules and judgment to a specific case). In the EU, most financial regulation is based in the Member State where the financial firm is incorporated or has a headquarters. Supervision is based on the principle of home country control in which the supervisor of the jurisdiction where the bank is chartered or incorporated exercises extraterritorial regulatory responsibility over the bank's EU operations. However, when an EU-based banking group has subsidiaries operating in other EU states, the supervision of those subsidiaries is exercised by the host state supervisor of the jurisdictions where the subsidiaries are incorporated.

The regulatory policy incentives of home country regulators are to protect the depositors and creditors of banks based in their home jurisdictions. This works as long as banking activities are largely confined to one country - normally the country where the bank is incorporated and has its home license. It has also worked well for banking groups which have fragmented management structures in which the management of foreign subsidiaries is largely autonomous from the day-today management of the parent group, hence allowing the foreign subsidiaries' management to deal independently with host state supervisors.

However, as global financial markets have become more inter-connected, the structure of banking markets and their management have changed significantly. Large banking groups have been created from a growing number of cross-border bank mergers. As a result, many banking groups today have major operations in multiple jurisdictions where they can pose systemic risk to a host state banking system. In addition, large banks are increasingly dependent on international capital markets for much of their funding. Banking groups are also progressively centralising a number of key functions at the group level. For instance, risk management, liquidity management, funding operations and credit control, are typically exercised at the group level or in specialised affiliates in order to gain economies of scale and synergies in specialist operations. This also has led to the distinction between branches and subsidiaries becoming blurred. For instance, it is no longer the case that a large subsidiary bank operating in one jurisdiction will be allowed to stay in business if its parent company bank defaults or fails in another jurisdiction (at least not for the short-run).

These market changes pose a number of challenges for the existing EU regulatory and supervisory framework. A financial crisis in Europe is now more likely to have substantial cross-border implications than the financial crises of the past. In response, the Commission proposed in 2009 several regulations that are now before Parliament and which build on the De Larosiere Commitee's Report in February 2009 that recommended increased institutional consolidation at the EU level to enhance micro-prudential supervision of cross-border financial institutions and macro-prudential surveillance of systemic risk in the broader EU financial system.

\section{The home country control model}

EU legislation has traditionally applied the principle of home country control to the cross-border operation of banks and other financial institutions, which holds that regulatory authority over banks that conduct activities through their branches in other member "countries" lies 
with the competent authorities in the EU/EEA state where the institution's head office is incorporated: see Council Directive 89/299/EEC of the European Parliament and Council of April 17, 1989, OJ 1989 L 124, p 16; and Council Directive 89/646/EEC of the European Parliament and Council of December 15, 1989 (OJ 1989 L 386, p 1); Directive 2000/12/EC of the European Parliament and Council of March 20, 2000 relating to the taking up and pursuit of the business of credit institutions, OJ $20000 \mathrm{~L}$ 126, p 1. Reference should also be made to Peter Paul and others $v$ Federal Republic of Germany, judgment of the Court of Justice of the European Communities, Case C-222/02, October 12, 2004 (recognising that Member State national authorities had a number of supervisory obligations pursuant to EU law vis-à-vis credit institutions and the exercise of those obligations throughout the Community based on the principle of home country control).

According to minimum harmonisation, Member States are required to harmonise what are considered to be the essential areas of banking regulation while being free to surpass these essential minimum standards and to maintain higher distinctive regulatory practices in areas not harmonised so long as they are pursuing valid public policy objectives and do not unnecessarily infringe on EC Treaty freedoms: see Caixa-Bank France v Ministere de l' Economie, des Finances et de l' Industrie, judgment of the Court of Justice of the European Communities, C-442/02, October 5, 2004 (invalidating a French legislative prohibition on the payment of interest for "sight" accounts for a French subsidiary of a holding company based in another EU state because it constituted an unnecessary restriction on freedom of establishment for the holding company, though the French government justified its prohibition on the grounds of consumer protection and promoting medium and long-term savings). The effective application of the home country principle based on minimum standards and mutual recognition is premised on the pursuit of common regulatory objectives and trust between regulatory authorities.

EC financial services Directives have traditionally adopted a functionalist approach to financial regulation by requiring the same type of activity to be subject to the same regulatory rules, even though the activity may be performed by different types of financial institutions (eg universal bank or investment bank): see First Banking Directive (1977), article 1; Second Banking Directive (1989), article 1(6). Moreover, EC legislation does not require Member States to adopt a particular institutional structure of financial regulation (although this has changed somewhat in the securities area, as EU states are now required to establish a single enforcement authority to enforce the Market Abuse Directive and a single listing authority for all issuers to file prospectuses under the Prospectus Directive. States may use a single regulator for prudential supervision (ie the UK FSA or German Bafin) a central bank for prudential regulation and a capital market regulator for conduct of business (so-called "twin peaks" approach, as in the Netherlands), or a three-pillar institutional model (banking, insurance and securities) along sectoral lines. In some systems, the central bank plays an important role in overall prudential supervision and in regulating the clearing and settlement system (Italy), while in other countries a regulator or supervisor exercises these functions (the UK).

Nevertheless, the EU regulatory and supervisory framework of home country control based on mutual recognition and minimum standards has accomplished a great deal in promoting the objectives of the European internal market but has recently come under strain because of growing integration in key areas of European banking and capital markets and cross-border risk exposures. Indeed, the credit and financial crisis that began in 2007 demostrates the cross-border nature of systemic risk in global as well as EU financial markets through, for instance, counterparty exposures in the money markets and disruptions to the cross-border operations of many large banking groups and financial conglomerates. The crisis has demonstrated the inadequacy of the EU's existing supervisory and crisis management framework.

\section{The Lamfalussy model and institutional consolidation}

The role of EU Member State institutions in regulating financial markets has undergone significant changes as well in recent years. The EU Financial Services Action Plan (FSAP) recognised the Lamfalussy four-level framework as essential in achieving the EU Treaty objectives of an open internal market for capital movement and trade in financial services. The four levels consist of:(1) legislative proposals of high level principles through the traditional EU codecision process; (2) based on the legislative proposals, EU finance ministers agree to implementing measures for Member States; (3) Member State regulators make proposals to Level 2 finance ministers regarding the implementing measures and then consult with each other regarding implementation; and (4) national compliance and enforcement (see Lamfalussy Committee, The Final Report of the Committee of Wise Men on the Regulation of European Securities Markets, February 15, 2001, Brussels). The process now applies to all major financial sectors, including banking, securities, insurance and pension fund management (Commission Decision 2001/527/EC (6 Jan 2001) (establishing Committee of European Securities Regulators); Commission Decision 2004/5/EC (5 Nov 2003)(establishing Committee of European Banking Supervisors); and Commission Decision 2004/6EC (establishing Committee of European Insurance and Operational Pensions Supervisors (CEIOPs)).

The three so-called Lamfalussy Level 3 networks presently consist of the Committee of European Securities Regulators (CESR), the Committee of European Banking 
Supervisors (CEBS), and the Committee of European Insurance and Occupational Pensions Supervisors (CEIOPS). These three committees have been acting in a regulatory capacity and prior to the crisis were successful in expediting the regulatory standard-setting process by making it more flexible and efficient. The successful operation of the regulatory networks depends on cooperation and frequent contacts between Member State supervisors. To this end, the committees have begun a number of initiatives to increase cooperation and convergence; but the changing structures of financial markets necessitates further institutional coordination in the Level 3 committees to address the growing crossborder effects of financial crises and the cross-border activities of large financial groups.

The Lamfalussy programme does not create a legislative competence to supervise financial markets at the European level. Indeed, the original Report of the Committee of Wise Men in 2000 envisioned only two principal functions for the Level 3 committees: (1) technical advice regarding the development of implementing measures, and (2) promotion of consistent implementation of Community legislation and enhancement of convergence in EU supervisory practices. It is essentially a regulatory process that relies on existing comitology procedures to develop EU financial legislation based on proposals from national finance ministers and regulators, in consultation with industry. Although the early stages of implementation of the Lamfalussy programme ignited some controversy concerning the scope of legislative authority for EU institutions, it has resulted in streamlined decisionmaking, promoted a wide ranging dialogue with industry and consumer groups and has disseminated its work and proposals to all relevant stakeholders. The Council and Parliament have recognised the early success of the Lamfalussy programmes and the ongoing work of the networks of the three regulatory committees.

The Lamfalussy framework has, however, been criticised as being too slow and lacking the institutional capacity to respond effectively to a cross-border financial crisis within the European Union (Alexander et al, 2007). Prior to the crisis, EU authorities had recognised that the changing structure of European financial markets and the cross-border operations of large banking groups necessitated further institutional consolidation at the EU level and in particular raised important issues regarding how much authority the three Level 3 committees should be given in overseeing national supervisors and cross-border firms and wholesale capital markets: see CEBS and the European System of Central Bank's Banking Supervisory Committee (BSC) Joint Guidance (2006) (extending the guidance role of the Level 3 committees from "going-concern" activities to crisis management cooperation). Moreover, the International Monetary Fund's surveillance reports identified the weak link in EU supervisory arrangements to be the absence of a clear framework of coordination between EU national supervisors with respect to the oversight of the cross-border operations of financial groups in EU states: IMF article IV Surveillance Report, (2007) p 27, and see also IMF article IV Surveillance Report (2006) para12. The recognised weaknesses in the EU institutional framework of financial supervision became even more apparent in 2007 and 2008 when the credit crisis incapacitated wholesale financial markets and EU supervisory authorities were unable to respond in a coherent or effective manner.

\section{Macro-prudential and micro-prudential supervision}

A major weakness in the Lamfalussy framework and in most EU Member States' prudential regulation was that supervisory practices were focused primarily on individual financial firms and investors, while not taking into account broader macro-economic factors, such as aggregate levels of risk in the financial system or how risk was being shifted to non-bank firms and investors in the broader capital markets. Supervisory practices were focused narrowly on individual firms, while neglecting structural developments in capital markets and in clearing and settlement systems. For instance, one of the major failures in UK regulation over the last 10 years was that prudential regulation was too market-sensitive; it focused on the individual institution and did not take into account the level of risk or leverage building up in the whole financial system. The UK FSA's supervisory approach was largely microprudential, that is, that if individual firms were managing their risk appropriately, then the financial system would be stable. This failed to take into account the fallacy of composition that what appears for individual firms to be rational and prudent actions in managing their own risk exposures under certain circumstances can, if followed by all firms, potentially produce imprudent or sub-optimal outcomes for the whole financial system.

In the case of the UK, excessive reliance on principlesbased regulation (PBR) also exacerbated weaknesses in the UK supervisory framework. The PBR approach focused on incentivising individual firm to experiment with different risk management practices so long as they achieved satisfactory firm outcomes that were measured by firm performance (ie shareholder prices) and whether the FSA's 11 high level principles were being achieved (ie treating customers fairly). The FSA's PBR approach did not take into account the aggregate effect of firms' performance on the financial system in terms of leverage generated and liquidity risks from wholesale funding exposures. To address adequately these macro-prudential risks in the future, prudential regulation will necessarily become more rules-based at the level of the firm and at the level of the financial system.

The De Larosiere Report (2009) and the UK FSA's Turner Review (2009) support the creation of a macro-prudential regulatory regime that is directly linked to the microprudential oversight of individual firms. Macro-prudential regulation will change regulation for individual banks in two main areas: (1) the regulation of individual firms must take 
into account both firm level practices and broader macroeconomic developments in determining how regulatory requirements will be applied to firm risk-taking (ie linking the growth of asset prices and GDP with contra-cyclical bank reserves and liquidity ratios), and (2) limitations on the type of financial products and investments offered because of controls on the overall levels of risk-taking and leverage at the level of the financial system (ie limits on loan-to-value and loan-to-income ratios). Implementing macro-prudential regulation will require that micro-prudential regulation become more rules-based because tighter ex ante constraints will be needed for the risk exposures of individual firms (ie leverage ratios and limits on maturity mismatches in wholesale funding). Prudential regulation will gradually become more rules-based in order to achieve macroprudential objectives. Macro-prudential regulation will change the nature of PBR because the supervisory focus will be expanded to include the application of macro-prudential controls to the broader financial system. Naturally, this will create new incentives for market participants to avoid the requirements by adopting new financial instruments and structures which may lead to new regulatory risks. Supervisors and central banks should be vigilant therefore as to how the market may respond to new macro-prudential controls.

The new focus on macro-prudential supervision will require supervisors to engage in surveillance of the financial system by monitoring aggregate leverage in the markets, the inter-connectedness between firms (large and small) in wholesale funding markets, and the impact of monetary policy on financial markets. Supervisors will also have to take into account macro-prudentual factors in deciding how to apply micro-prudential controls on individual firms. Any consideration of a future model of EU supervision must take into account the links between micro-prudential regulation of individual firms and macroprudential oversight of the financial system.

\section{Macro-prudential supervision and the central bank's role}

Most central banks have a mandate to assess and monitor financial stability which necessarily involves them in collecting supervisory information from banks and financial markets. A central bank would be well-situated to conduct macro-prudential supervision because it has access to data on the economy and financial markets comprising both market intermediairies, markets and market infrastructures. Wide access by central banks to supervisory information renders their financial stability assessment more accurate and effective in forecasting and monitoring systemic stresses. Similarly, supervisors may find the macro-prudential assessment useful in providing them with information to monitor certain categories of risk. The central bank can more effectively discharge its financial stability functions - ie overseeing the payment and settlement systems - by having access to micro- prudential data, while supervisors (whether inside or oustide the central bank) can enhance their risk assessments of individual firms by using macro-prudential data. This two-way flow of information between central banks and supervisors is the basis for the Financial Stability Forum's 2008 report suggesting enhanced interaction and exchange of information between central banks and supervisors.

This type of interplay between macro-prudential assessors and micro-prudential supervisors has not occurred in the EU states where central banks are prohibited from conducting micro-prudential supervision and are left with the broader macro-prudential tasks of overseeing the payment and settlement system, monetary policy, and financial stability assessments. This is the case with the European Central Bank (ECB) which is expressly prohibited from engaging directly in prudential supervision under Article 127(6) of the Treaty on the Functioning of the European Union (TFEU). Nevertheless it has responsibility to "contribute to the smooth conduct of policies pursued by the competent authorities relating to the prudential supervision of credit institutions and the stability of the financial system" (Art 127 (5) TFEU). How might the ECB "contribute to the smooth conduct of policies" in the Eurosystem and throughout the EU without having access to supervisory information? An examination of the EU legal framework applicable to the exchange of information between central banks and supervisory authorities suggests that the EU regime is "asymmetric" because although the ECB and European System of Central Banks are obliged to contribute to the smooth functioning of supervisory policies, supervisory authorities do not have an equivalent responsibility to contribute to the tasks of the ECB or ESCB. Until this asymmetry is rectified, the EU will fail to have effective macro-prudential supervision.

\section{THE COMMISSION'S PROPOSALS FOR MICRO-PRUDENTIAL AND MACRO- PRUDENTIAL SUPERVISION}

The Commission's legislative proposals build on the proposals of the High Level committee chaired by Jacques de Larosiere. The proposed regulations to establish a European System of Financial Supervisors (ESFS) and a European Systemic Risk Board (ESRB), consisting of three ESAs, will lead to significant institutional consolidation of European financial supervision and macro-prudential oversight. The creation of a ESFS would lead to important changes for the operations and functions of the three Level 3 Lamfalussy committees by creating three ESAs with legal personailty and authority to ensure consistent application of EU financial legislation. The creation of a ESRB aims to enhance EU Member States' capacity to assess and monitor systemic risks across European and global financial markets and to obtain data from supervisors on large systemic financial institutions and wholesale financial markets. 


\section{European Systemic Risk Board (ESRB)}

The ESRB was established to be the main body responsible for macro-prudential oversight and surveillance of EU financial markets. ESRB Regulation, article 3(1) (proposed) states:

\section{"The ESRB shall be responsible for the macro-prudential oversight of the financial system within the Community in order to prevent or mitigate systemic risks within the financial system, so as to avoid episodes of widespread financial distress, contribute to a smooth functioning of the Internal Market and ensure a sustainable contribution of the financial sector to economic growth."}

Despite its lack of formal institutional structure, it has a broad remit to exercise a number of important functions in the field of macroprudential oversight, including monitoring sources of systemic risk and other risks to financial stability across EU countries and financial sectors and serving as an institutional voice for EU central bankers in shaping and developing macroprudential supervisory practices. It also will interact with global financial stability bodies to develop effective early warning systems. The ESRB will aim to identify and prioritise the risks and use stress testing and other methodologies to analyse how they can impact financial stability.

The ESRB would consist of 61 representatives and officials consisting of the EU central bank governors, representatives of the European Supervisory Authorites, the Economic and Finance Committee, and the European Commission, all serving on a General Board. The ESRB secretariat would be entrusted to the European Central Bank; the legal basis of the Regulation is Article 114 of the Treaty on European Union (as amended).

Under the proposal, the ESRB would monitor and assess systemic risks arising from individual banks and across the whole European financial system. In doing so, it will seek to draw connections between macro-economic conditions and structural developments in financial markets, and identify vulnerabilities with particular institutions. The ESRB would also issue recommendations and warnings to countries or financial groups or other concerned entities and would report all recommendations and warnings to the Council of Ministers. The ESRB would devise specific follow-up procedures and "moral incentives" to follow recommendations or explain why not. The ESRB can inform the Council if unsatisfied with a Member State or entity's explanation and can conduct "name and shame" publicity if necessary.

The ESRB will be assisted by a steering committee that will assist it in decision-making, reviewing and preparing for meetings of the General Board, and monitoring the ESRB's work progress. The steering committee membership will be the chair and vice-chair of the ESRB; five other members of the General Board who are also members of the General Council of the ECB (who will be elected by and from the central bank members of the General Board for two year periods); a member of the European Commission; the Chairs of each of the ESAs; and the president of the Economic and Financial Committee. The Regulation confers a specific role for the European Central Bank in the ESRB's operation: the ECB's President and Vice President will serve on the ESRB Board.

The ECB would provide the secretariat for the ESRB while performing administrative, logistical and analytical support. This would also include drawing on technical advice from the 27 EU national central banks and supervisors (see speech of Jose Manuel Gonzalez-Paramo, Member of the Executive Board of the ECB, January 22, 2010, p 4)

Some economists, however, have raised concerns that the ESRB would not be able to perform its function of identifying and monitoring systemic risk because there is inadequate understanding of the causes of systemic risk and that the proposed ESRB Regulation does not provide any information on what systemic risk means and how to measure it (see oral evidence of Jon Danielsson, The Committee's Opinion on proposals for European financial supervision, House of Commons Treasury Committee (Sixteenth Report of session 2008-09), Ev 1). Accordingly, it was argued that the design of the ESRB is flawed and should be substantially revised. In addressing this concern, it is submitted that although systemic risk is difficult to measure, and its causes are even more difficult to identify precisely (especially for a future financial crisis), EU policymakers should not conclude therefore that they should not try to establish institutional frameworks to monitor systemic risks across EU financial markets. Indeed, the financial crisis demonstrates that macroprudential risks are evident in the European financial system (see "Financial Supervision and Crisis Management in the EU” (December 2007), K Alexander, J Eatwell, A Persaud, and R Reoch, Commissioned Report for the European Parliament Committee on Economic and Monetary Affairs, pp 2-3, 17-18). Banks have exposure to each other throughout Europe in the money markets through a variety of risk exposures, and European policymaking needs to have better surveillance of the systemic risks posed by certain banking groups and financial institutions that operate in Europe.

The crisis also demonstrates that systemic risk arises in the wholesale capital markets - especially through the securitisation and the over-the-counter credit default swap markets - as well as from individual financial institutions. The Turner Review recognised that the sources of systemic risk can be macro-prudential in nature and that this necessitates that central banks and regulators establish enhanced cross-border (international and European) frameworks for identifying and monitoring macroprudential systemic risks and, in certain circumstances, for issuing early warnings to affected countries. The absence of a consensus view on the sources of systemic risk 
therefore does not preclude the design of effective crossborder institutional structures to monitor and measure systemic risks in European financial markets.

Other critics raised the concern that the composition of the ESRB was too heavily weighted in favour of central bankers and in particular favouring the ECB and that the ESRB lacks democratic accountability. Professor Willem Buiter for example observed that a ESRB dominated by EU central bankers should not be given such an important role because over the last decade "the ECB, the Eurosystem NCBs, and the rest of the national NCBs [had] not exactly covered themselves with glory in the area of macro-prudential supervision and regulation": see "The Committee's Opinion on proposals for European financial supervision", House of Commons Treasury Committee, (Sixteenth Report of session 2008-09) p 18. Also, because all decisions to bail out a bank or provide other crisis assistance requires approval of national fiscal authorities, finance ministries should also be represented on the ESRB.

Nevertheless, the ESRB's absence of legal personality provides it with more institutional flexibility and scope to fulfil its core functions and broad mandate to monitor the whole European financial system. It also allows the ESRB to interact flexibly with the ESAs and Member State supervisors to form a common framework of regulation that allows for regulatory innovation to address evolving market risks. However, the ECB's integral role in providing administrative support, and overseeing and discharging the operations of the ESRB, is constrained by Article 114 (6) TFEU that requires a unanimous vote by the Council for the ECB to carry out any function for the ESRB that directly involves the prudential supervision of financial institutions. So the extent and scope of the ECB's secretariat role may be limited to functions not involving macro-prudential supervision if not approved by a unanimous vote in Council.

\section{The European System of Financial Supervisors (ESFS)}

The ESFS would consist of a network of Member State supervisors that would operate within three different ESAs with responsibility for banking, insurance and securities markets, respectively (Regulation of the European Parliament and of the Council $\operatorname{COM}(2009) 503$ (establishing a European Securities and Markets Authority), $\operatorname{COM}(2009) 502$ (establishing a European Insurance and Occupational Pensions Authority), and $\operatorname{COM}(2009) 501$ (establishing a European Banking Authority)). Each Member State supervisor would continue to be responsible for discharging its supervisory functions, but under the proposed regulations would have to account for its supervisory practices to the relevant ESA. Each ESA will be responsible for adopting a harmonised rule-book, technical standards and guidance for the application and implementation of EU financial legislation. The ESAs would provide a point of contact for national supervisors to interact and coordinate their oversight of cross-border financial firms and address matters of mutual concern between Member State supervisors and the ESAs. The ESAs would perform specifically delegated tasks, such as mediating disputes between supervisors and, if necessary, resolving disputes. As discussed below, their most important immediate responsibility would be to formalise the operations of the colleges of supervisors which presently oversee the cross-border operations of Europe's largest 50 or so banks and financial institutions.

The decision to build the ESFS along sectoral lines banking, securities and insurance - was influenced significantly by the existing sectoral approach of the Lamfalussy framework. EU policy makers could have diverged away from the Lamfalussy sectoral approach by proposing instead to create a single EU financial supervisor for all financial services, or alternatively a single EU supervisor for each of the three financial sectors. Rather, the Commission chose to build directly on the existing framework by transforming the three Level 3 supervisory committees into more formalised institutional structures with legal personality and the power to resolve disputes between supervisors and to issue Directives enjoining supervisors to bring their practices into compliance with EU law and regulatory codes. This path-dependent approach recognised that the transaction costs - both institutional and political - would have been much higher if EU policymakers had proposed a more dramatic institutional shift away from the Lamfalussy framework. Also, equally important, the use of the Lamfalussy institutions on which to build the ESFS recognised that a new formalised EU institutional structure was nevertheless to be firmly and primarily anchored in Member State competence to supervise financial markets. The ESFS/ESA framework builds on the existing decentralised Member State supervisory approach by enhancing the ability of supervisors to coordinate cross-border oversight along with enhanced accountability to other Member States to ensure faithful implementation of EU law.

Moreover, the proposed institutional framework recognises the interdependence between micro- and macro-prudential risks across EU financial markets and the need to be accountable to the views of market participants and all EU stakeholders, including financial institutions, investors and consumers. It provides a more consolidated and rational institutional design for linking micro-prudential supervision of individual firms with the supervision of the linkages between institutions and between institutions and the broader financial system. The ESRB is expected to provide a broader perspective of the financial system and to interact with supervisors in monitoring and assessing system-wide risks. In this capacity, the ESRB would serve as the basis for developing a more integrated EU supervisory structure that would improve consistency in regulatory and supervisory practices and approaches across EU/EEA states, thus creating a level playing field and a more efficient regulatory 
framework for controlling systemic risk and preventing market failure

\section{The ESFS and Colleges of Supervisors}

The ESFS would place greater emphasis on using colleges of supervisors from EEA states to supervise the operations of Europe's largest cross-border banks and financial institutions. The proposed European Banking Authority (formerly the Lamfalussy Level 3 Committee of European Bank Supervisors (CEBS)) would have responsibility for overseeing the implementation of guidelines and decision-making procedures for the colleges. Membership of the colleges would include: All EEA supervisors of subsidiaries; EEA supervisors of branches recognised as significant; third country supervisors with equivalent confidentiality provisions; and central banks as appropriate. Moreover, the Capital Requirements Directive (CRD) (Art 131a) provides the legal basis for a single college for global EEA-based banks.

The main function of colleges will be to exchange information between supervisors, coordinate communication between supervisors of the financial group, voluntary sharing and/or delegation of tasks, joint decision on model validation (eg Basel II). The colleges will also be involved in joint risk assessment and joint decision on the adequacy of risk-based capital requirements. The planning and coordination of supervisory activities for the financial group and in preparation of and during emergency situations (ie crisis management). The ESAs will have oversight of the colleges and will have authority through conciliation and mediation to resolve disputes between member authorities in the colleges. Some concern has been expressed that this power of conciliation and mediation might infringe Member State fiscal autonomy, but the better view holds that these concerns are exaggerated as the ESAs will only be able to resolve disputes and devise rules and technical standards for national supervisors based on existing EU financial legislation.

\section{The fiscal autonomy of Member States}

The proposals for the ESFS and ESRB provide no authority for EU institutions to order Member States to spend taxpayer funds in a crisis (ie bail out a bank). Indeed, the Commission proposals do not provide a crisis management mechanism that would require a member authority to use public funds in a crisis. In other words, the sovereignty of Member States with respect to their fiscal prerogative to support ailing financial institutions has not been intruded upon. In fact, the fiscal safeguards provision of article 23 of the ESA does not permit the ESAs to take any measures under articles 10 or 11 that would require a Member State to make fiscal expenditures. The fiscal safeguards provision applies to the authority of the ESAs to resolve disputes between member supervisors under article 11.
Some Member State Parliaments, however, have expressed concern that the fiscal safeguard provisions of article 23 only apply to orders issued by an ESA under articles 10 and 11, and that an ESA could potentially order a member authority under some other article of the regulations to take action that might involve fiscal expenditure. This possibility was pointed out with respect to article 21 of the ESA regulations which authorises the ESAs with Commission approval to order a member authority to comply with a recommendation or warning issued by the ESRB. Council addressed these concerns by amending the ESA regulations to make it clear that no order of a ESA could require a Member State to use public funds.

It should be noted however that pursuant to article 9 of the regulations the ESA would have authority to order a member authority to comply with existing EU financial legislation and the ESA codes and technical standards implementing such legislation, which may indirectly involve the Member State spending public funds. The relevant EU financial legislation which an ESA can order a Member State to comply with are listed in the respective regulations establishing a European Banking Authority, a European Securities and Markets Authority, and a European Insurance and Occupational Pension Authority.

Another area of possible legal challenge concerns the Commission's use of Article 114 (ex art 95) of the Treaty as the legal basis to adopt the regulations creating the ESAs and the ESRB. Article 114 (ex art 95) authorises EU institutions to create EU agencies and other EU bodies with delegated powers to facilitate the harmonised implementation of EU law. However, the scope of delegated authority under Article 114 to these EU agencies/bodies is limited by the so-called Meroni doctrine that holds that EU agencies cannot be delegated ultra vires powers (that is, powers that are not conferred on EU institutions) to implement EU law. Moreover, ECJ jurisprudence also prohibits EU institutions from delegating intra vires powers to EU agencies or bodies if such powers delegate substantial discretion to EU agencies to adopt rules and standards or take other related decisions to implement EU law. For instance, the Commission's delegation of authority to the ESAs to promulgate a harmonised EU regulatory code and technical standards that create a level regulatory playing field between Member States vests considerable decision-making authority in the ESAs not only to devise a EU regulatory code but also to decide if states and financial firms are in breach of the code and to order the relevant Member State regulators to take remedial action. Although Commission approval must be obtained before the ESA codes and standards become effective, considerable discretionary rule-making and enforcement authority has been delegated to the ESAs.

These constitutional concerns have already been raised by the UK Parliament (Treasury Committee Report, 2009) and may possibly form the basis of legal challenges by Member States or certain financial institutions subjected 
directly to the EU code. Nevertheless, these constitutional concerns may legally be justified by the fact that EU institutions can be authorised by qualified majority vote to exercise certain limited competences in the supervisory field and the proposed framework requires that the ESAs consult and obtain the Commission's approval before imposing any order or Directive against a Member State or a financial institution based in a Member State.

\section{Establishing a single EU supervisor?}

Considerable support has emerged for a single EU financial supervisor across financial sectors or for a sectoral approach along the lines of banking, securities and insurance (Andenas \& Avgerinos 2003 (suggesting the ECB as supervisor); Avegerinos 2003 (suggesting an EU SEC) especially in light of the financial crisis (ESFRC 2009). The main argument for institutional consolidation at the EU level is that Europe's growing internal financial market is much more integrated - both at the level of the financial system and at the level of firms operating cross-border - which cannot be supervised efficiently by Member States because of different institutional capacities for implementation and enforcement. A centralised supervisory body would promote a level playing field in supervisory practices by overseeing the activities of Member State authorities and coordinating and conducting cross-border surveillance and enforcement. The creation of an EU supervisor could potentially reduce the high transaction costs of monitoring and enforcing EU law on a cross-border basis. Further, a single supervisor could assist with resources and training for some member authorities in need of assistance.

Although there are recognised benefits to such a centralised institutional structure, there are some concerns regarding the sovereignty costs states would incur by allowing such an authority to have jurisdiction to monitor and enforce EU law in their jurisdictions. An extensive literature has emerged questioning the utility and effectiveness of the single supervisory model for Europe (Vives 2001, Ferran, 2005). Moreover, on constitutional grounds, there are critics who assert that the Commission and EU bodies do not have a conferred power to engage in prudential supervision or even macro-prudential surveillance (House of Commons 2009) According to this view, the Meroni doctrine would prohibit the Commission and Council from creating an EU agency and then delegating powers to the agency to supervise EU financial markets on the grounds that prudential supervision has not been conferred by the Treaty on EU institutions and therefore cannot be delegated to a newly created EU supervisory agency.

For those in favour of more institutional consolidation, the Commission's proposals to create the ESAs should be welcomed because the Treaty would probably be interpreted as prohibiting any further institutional consolidation in supervision in the form of a single EU supervisor for all financial markets or a single EU supervisor along financial sector lines. Despite the potential legal challenges on "delegation of power" grounds, the exercise of financial supervision will remain decentralised and based at the Member State level. The Commission's proposals therefore may withstand constitutional challenge because they maintain the essential decentralised supervisory structure with Member States exercising ultimate competence to supervise financial markets while building lines of accountability to other EU states through the European supervisory agencies.

Nevertheless, there remains an important objection to the proposals on public policy grounds that they do not go far enough. In the aftermath of the crisis, there have been proposals to establish a single EU supervisor for the largest 50 or so financial institutions with cross-border operations throughout Europe. Their significant regional, and indeed global, scope makes them amenable to a transnational supervisory structure that is consolidated at the European level in the form of a single EU prudential supervisor that would have full competence to supervise these firms and their foreign branches and subsidiaries. Similarly, a single EU supervisor could also play an important role in supervising the growing inter-connected infrastructure of EU capital markets, in particular the clearing houses and certain settlements systems that operate at EU level.

As mentioned above, an important rationale for this is that national supervisors have high transactions costs in supervising the cross-border dimension of financial markets and a single EU supervisor can reduce these transaction costs by coordinating the activities of member authorities. The rationale for this is not only that it would be extremely difficult for national supervisors to obtain a clear picture of these institutions and their operations, but even more because their potentially risky operations may create significant cross-border externalities, which makes supervising them solely by one national supervisor suffer from a serious incentive problem. Further consolidation of EU supervision, however, would not be permitted by the Treaty. The 2009 Lisbon Treaty for the Effective Functioning of the European Union crystallises this institutional limitation. But some argue that politicians should address this absence of Treaty authority for creating a single EU supervisor by amending the Treaty to allow this to be done (ESFRC 2009).

\section{CONCLUSION}

European financial markets are increasingly integrated in terms of cross-border operations of institutions and wholesale capital markets and system infrastructure. EU financial regulation needs more effective supervision that links micro-prudential supervision with macro-prudential oversight of the financial system. Although the European Central Bank is responsible for contributing to the smooth operation of eurozone payment systems, it is prohibited legally from engaging in prudential supervision unless it obtains unanimous support from EU states. Therefore, 
the more realistic debate regarding which supervisory model to adopt for Europe involves the extent to which institutional consolidation should occur based on the Lamfalussy framework and the Commission's proposals which build upon it, or should a EU supervisor be created that is not a central bank but has full competence to supervise and regulate EU financial markets? Any proposal for the latter would be controversial and attract much political criticism from many EU states and would legally be unsound on Treaty grounds.

In the meantime, the Commission's proposals, though institutionally complex, essentially maintain Member State competence to supervise markets, but require supervisors to coordinate their actions with respect to cross-border firms and incorporating systemic risk concerns into their supervisory practices. Overall, the proposed ESFS and ESRB are adequate institutionally to build an effective macroprudential supervisory framework that is durably linked to micro-prudential supervsion. However, simply creating new EU institutions is not enough. EU policy makers should also be concerned with the substantive requirements of financial legislation and whether they are creating an incentive compatible framework that limits systemic risk.

Another important area that should be recognised is that crisis prevention - through prudential supervision - and crisis management - mitigating a crisis by resolution - are part of a seamless process. Effective prudential supervision also requires effective crisis management mechanisms, which include resolution procedures for banks and other systemically important firms, policies regarding too big to fail banks, and deposit insurance. Indeed, the ESAs are not authorised to engage in crisis management and would have no authority to use public funds to resolve bank failures or some other systemic problem involving a financial institution. Therefore, their ultimate effectiveness can be called into question. Is it really realistic to create EU bodies with ex ante responsibilities for micro and macro supervision while not having the authority to bail out, nationalise, or unwind a large bank or engage in other financial rescues? The link between crisis prevention and crisis management therefore should be high on the EU policy agenda and without a better balance between the two at the EU level the present proposals for institutional reform will be ineffective.

\section{Professor Kern Alexander}

The author holds the Chair in Banking, Commercial and Financial Market Law at the University of Zurich Law Faculty and is Director of Research in Financial Regulation at the Centre for Financial Analysis and Policy, University of Cambridge. This paper derives in part from his lecture at the Institute of Advanced Legal Studies on January 25, 2010.

\section{REFERENCES}

- Alexander, Kern, John Eatwell, Avinash Persaud and Robert Reoch (December 2007) "Financial Supervision and Crisis Management in the EU" (Brussels: EU Parliament).

- Andenas, Mads \& Yannis Avgerinos (eds) European Financial Markets and a Single Regulator (2003, London: Kluwer Law International).

- Avgerinos, Yannis The Need and Rationale for a European Securities Regulator (2004, Palgrave).

- The European Commission, "European Financial Integration Report 2009” (Brussels: 2009) Commission Staff Working Document: "European Financial Integration Report 2008” (Brussels, 2008)

- EU High Level Group on Financial Supervision in the EU, "The De Larosiere Report” (Brussels, 2009).

- European Shadow Financial Regulatory Committee (November 2009) "A new Life for European Financial Supervision”, Statement No 31 (Stockholm).

- Ferran, Eilis, Building an EU Securities Market (2005, Cambridge University Press).

- Gonzalez-Paramo, Jose Manuel (January 22, 2010), Speech, Presentation of the Report, Member of the Executive Board of the ECB (Madrid).

- Goodhart, Charles AE, (2000) The Oragnizational Structure of Banking Supervision, (London: The Financial Markets Group);

- 'The Regulatory Response to the Financial Crisis', Journal of Financial Stability (2008) 4: 351-358.

- House of Commons Treasury Committee, "The Committee's Opinion on proposals for European financial supervision", House of Commons Treasury Committee, (Sixteenth Report of session 2008-09, London: House of Commons).

- House of Lords Select Commmittee on Economic Affairs (June 2009) "Banking Supervision and Regulation," Volumes 1 \& 2 (London: House of Lords).

- Lastra, Rosa M, Legal Foundations of International Monetary Stability (2006, Oxford University Press).

- The Turner Review : A regulatory response to the global banking crisis, (March 2009, London, The Financial Services Authority).

- Vives, Xaxier, "Restructuring Financial regulation in European Monetary Union”, Journal of Financial Services Research (2001) 19: 57-82.

- Wymeersch, Eddy (2009), "The Structure of Financial Supervision in Europe: About Single Financial Supervisors, Twin Peaks and Multiple Financial Supervisors", European Business Organization Law Review 8: 237-306 (TMC Asser Press). 